\title{
The Brazilian Army nurses' uniforms: visual identity in World War II
}

\author{
Uniformes de enfermeiras do Exército Brasileiro: identidade visual na Il Guerra Mundial \\ Uniformes de enfermeras del Ejército Brasileño: identidad visual en la Segunda Guerra Mundial
}

Margarida Maria Rocha Bernardes'

ORCID: 0000-0003-2849-413X

Alexandre Barbosa de Oliveira"

ORCID: 0000-0003-4611-1200

Sônia Kaminitz"'I

ORCID: 0000-0001-6029-693X

Antônio Marcos Tosoli Gomesiv

ORCID: 0000-0003-4235-9647

Sérgio Corrêa Marques'v
ORCID: 0000-0003-2597-4875

Fernando Rocha Porto"'I

ORCID: 0000-0002-2880-724X

'Escola Superior de Guerra. Rio de Janeiro-RJ, Brasil.

" Universidade Federal do Rio de Janeiro. Rio de Janeiro-RJ, Brasil.

II Universidade Federal do Estado do Rio de Janeiro. Rio de Janeiro-RJ, Brasil.

IV Universidade do Estado do Rio de Janeiro. Rio de Janeiro-RJ, Brasil.

How to cite this article: Bernardes MMR, Oliveira AB, Kaminitz S, Gomes AMT,

Marques SC, Porto FR. The Brazilian Army nurses' uniforms: visual identity in World War II. Rev Bras Enferm [Internet]. 2019;72(1):111-7. DOI: http://dx.doi.org/10.1590/0034-7167-2018-0414

Corresponding Author:

Margarida Maria Rocha Bernardes

E-mail: margarbe@globo.com

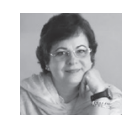

Submission: $06-12-2018$

Approval: 07-22-2018

\section{ABSTRACT}

Objective: To analyze the symbolic effects of the official military uniform of the nurses from Brazilian Army in World War II. Method: This research was developed using the historical method, with iconographic sources. The data were discussed based on the concepts of the social world theory, by Pierre Bourdieu. Results: The images selected demonstrate the own meaning of the uniforms, evidencing the functions and the social position of those who wear it, being private and obligatory to use it in the military field. Final considerations: In the case of the nurses from the Brazilian Expeditionary Force, the appropriation of uniforms promoted the visual communication representing military nurse in the context of war, at the same time it served for distinction purposes in the army, but not necessarily in the nursing field. Symbolically, they remained amongst the walls of the barracks even after the end of the war and, thus, they remained unknown and marked by the symbols of forgetfulness.

Descriptors: Nursing; Military Nursing; World War II; History; Clothing.

\section{RESUMO}

Objetivo: Analisar os efeitos simbólicos do vestuário militar oficial das enfermeiras do Exército Brasileiro na II Guerra Mundial. Método: A pesquisa foi desenvolvida usando o método histórico, com fontes imagéticas. Os dados foram discutidos à luz de conceitos da teoria do mundo social, de Pierre Bourdieu. Resultados: As imagens selecionadas demonstram o significado próprio dos uniformes, explicitando as funções e a posição social de quem os porta, sendo de uso privativo e obrigatório no campo militar. Considerações finais: No caso das enfermeiras da Força Expedicionária Brasileira, a apropriação de uniformes promoveu a comunicação visual da figura-tipo da enfermeira militar no contexto da guerra, ao mesmo tempo que conferiu distinção no âmbito do exército, mas não necessariamente no campo da enfermagem. Simbolicamente, elas permaneceram entre os muros dos quartéis mesmo após o término da guerra e, por conseguinte, mantiveram-se desconhecidas e marcadas pelos signos do esquecimento. Descritores: Enfermagem; Enfermagem Militar; II Guerra Mundial; História; Vestuário.

\section{RESUMEN}

Objetivo: Analizar los efectos simbólicos de la vestimenta militar oficial de las enfermeras del Ejército Brasileño en la II Guerra Mundial. Método: La investigación fue desarrollada usando el método histórico con fuentes de imágenes. Los datos fueron discutidos a la luz de conceptos de la teoría del mundo social, de Pierre Bourdieu. Resultados: Las imágenes seleccionadas demuestran el significado propio de los uniformes, explicitando las funciones y la posición social de quien los porta, siendo de uso privativo y obligatorio en el campo militar. Consideraciones finales: En el caso de las enfermeras de la Fuerza Expedicionaria Brasileña, la apropiación de uniformes promovió la comunicación visual de la figura-tipo de la enfermera militar en el contexto de la guerra, al tiempo que confería distinción en el ámbito del ejército, pero no necesariamente en el campo de la enfermería. Simbólicamente, permanecieron entre los muros de los cuarteles incluso después del término de la guerra, y, por consiguiente, se mantuvieron desconocidas y marcadas por los signos del olvido.

Descriptores: Enfermería; Enfermería Militar; Segunda Guerra Mundial; Historia; Vestuario. 
The Brazilian Army nurses' uniforms: visual identity in World War II Bernardes MMR, Oliveira AB, Kaminitz S, Gomes AMT, Marques SC, Porto FR.

\section{INTRODUCTION}

During World War II (1939-1945), the Brazilian Government was pressured by the United States of America to allow North American troops to use harbors and airports of the Northern and Northeast Brazil, which are strategic locations from a military perspective. On the other hand, the U.S. promised to provide new equipment for the Brazilian Armed Forces and construct a steel plant for Brazil. After successive torpedo attacks against Brazilian merchant ships by German submarines and an increasing internal and external political pressure, Getúlio Vargas, the then Brazilian President, declared war all over the country on August 31, 1942 by the Decree-Law No. $10.358^{(1)}$.

In the process of national mobilization for war, a corps of 67 nurses from the reserve of the Brazilian Army (EB), which was incorporated into the Brazilian Expeditionary Force (FEB), was officially created and trained. The corps went to the Italian front in July 7,1944 , returning to Brazil after the end of the conflict ${ }^{(2)}$. Prepared and worn with military uniform, they traveled to care for the wounded and for those in need of care because of the international conflict. The clothing was used as a visual communication inherent to the group's identity due to sociocultural patterns related to certain garments, which express the modus operandi of power relations and identity constructions $s^{(3)}$.

Thus, the social meaning of the clothing is expressed through its aesthetic. This reveals the intellectual and emotional connection between it and its user, considering the esthetic aspects of the body in motion, as well as the body structure and the social reference of fashion employed for manufacturing the clothing ${ }^{(4)}$. In the case of military uniforms, the cuts and shaping in the fabrics for shaping are presented with the objective of constructing the identification of badges of distinction in the group's hierarchy and the visual language of the institution. Thinking from this perspective is to connect mind and body to instill discipline in nurses in military fields. FEB's nurses were trained to incorporate the military habitus, implying the construction of a social identity created through the willingness of bodies to feel, think and act, a sort of "symbolic violence"(5).

In addition, the clothing and accessories are understood as a form of communication, which marks and deliberates relations between the groups. To this end, the object of this study is identity representation of nurses from FEB through the military uniform. In this study, topics related to culture, identity and organizational communication were interconnected with the notions of clothing, fashion and body.

The justification of this study is the need for amplifying the dialogue between nursing and researches on the representations od objects and symbolic marks of the profession, especially in the period of World War II, to identify the power and counterpower relations in the cultural construction of the identity of the female nurses in Brazil.

\section{OBJECTIVE}

To analyze the symbolic effects of the official military uniform of the nurses from Brazilian Army in World War II.

\section{METHOD}

\section{Ethical aspects}

For conducting this study, the approval by the Research Ethics Committee was not required, since the images were taken more than 70 years ago. Their restriction-free use is guaranteed by the Brazilian legislation on copyright ${ }^{(6-7)}$.

\section{Theoretical-methodological framework}

The analysis framework was based on the concepts of the social world theory, by Pierre Bourdieu.

\section{Type of study}

This was a historical approach study.

\section{Methodological procedures}

For obtaining photographic images, the bibliography and image archives on the object of this study were consulted. As basis for discussion, the nurse officers' scrapbooks and references related to the theme were used, and the findings were categorized, critically evaluated and treated according to the historical context.

The sources were uniform drawings and pictures of nurses wearing them.

\section{Hypothesis}

The signs added in official uniforms use by military nurses during the World War II were symbolic elements determinant in the perspective of the profession, and they have also allowed the definition of gender identity according to military habitus.

\section{Study scenario}

Archives available at the Oswaldo Cruz Foundation, specifically at the Fundo Virgínia Portocarrero, at Oswaldo Cruz's house, and Army Historical Archives (The Eastern military command), both located in the city of Rio de Janeiro, were consulted.

\section{Data source}

Historical sources were made up of drawings of uniforms and photos of nurses wearing them.

\section{Data collection and organization}

The images were searched and selected from August to December 2017. The selection criteria were: records obtained during the period of the World War II that represented the Brazilian military nurses wearing official uniforms made exclusively for them.

\section{Research steps}

After applied the criteria, a nankin sketch drawn by the FEB nurse Virgínia Maria Niemeyer Portocarrero and other two photographs of FEB nurses wearing officer walking uniform were selected for analysis. 


\section{Data analysis}

For image processing, an evaluation matrix consisting of identification data, content strategy, communication plan and relevant data from other sources was used ${ }^{(8)}$. After using this matrix, the data were submitted to triangulation of sources linked with the context for discussion with the literature inherent to the object of study.

\section{RESULTS}

Several atypical situations about the work of Brazilian women in World War Il were reported by the nurses from the FEB in their scrapbooks. Some studies ${ }^{(9-10)}$ were conducted to reveal the memory and the history of this first group of female nurses in the Brazilian Armed Forces, but in this study, unlike the others, we opted for analyzing the garments used in war scenarios.

As mentioned in the previous section, Figure 1 is a sketch found in the war diary of the FEB's nurse Virginia Maria Niemeyer Portocarrero. This source records the military uniform of the Brazilian nurses and illustrate the type of function and culture that the garment communicates. In the social spaces of the interactions, the nurses should wear symbolic attributes of authority linked with their position in the armed forces.

The sketch shows elements of uniforms such as: a bag with strap, for use on the shoulder (front and lateral); front and back of a jacket with four buttons, adjusted at the waist; a badge on the shoulders; and a beret with the coat of arms of EB. These elements of military uniforms were inspired by the male military uniforms, considering the variations in the way women wear.

Figure 2 shows the FBE nurse Lucia Osório before embarking to the Italian front. She was enrolled in the school of physical education of the army, located in Fortaleza de São João (Urca - Rio de Janeiro, RJ).

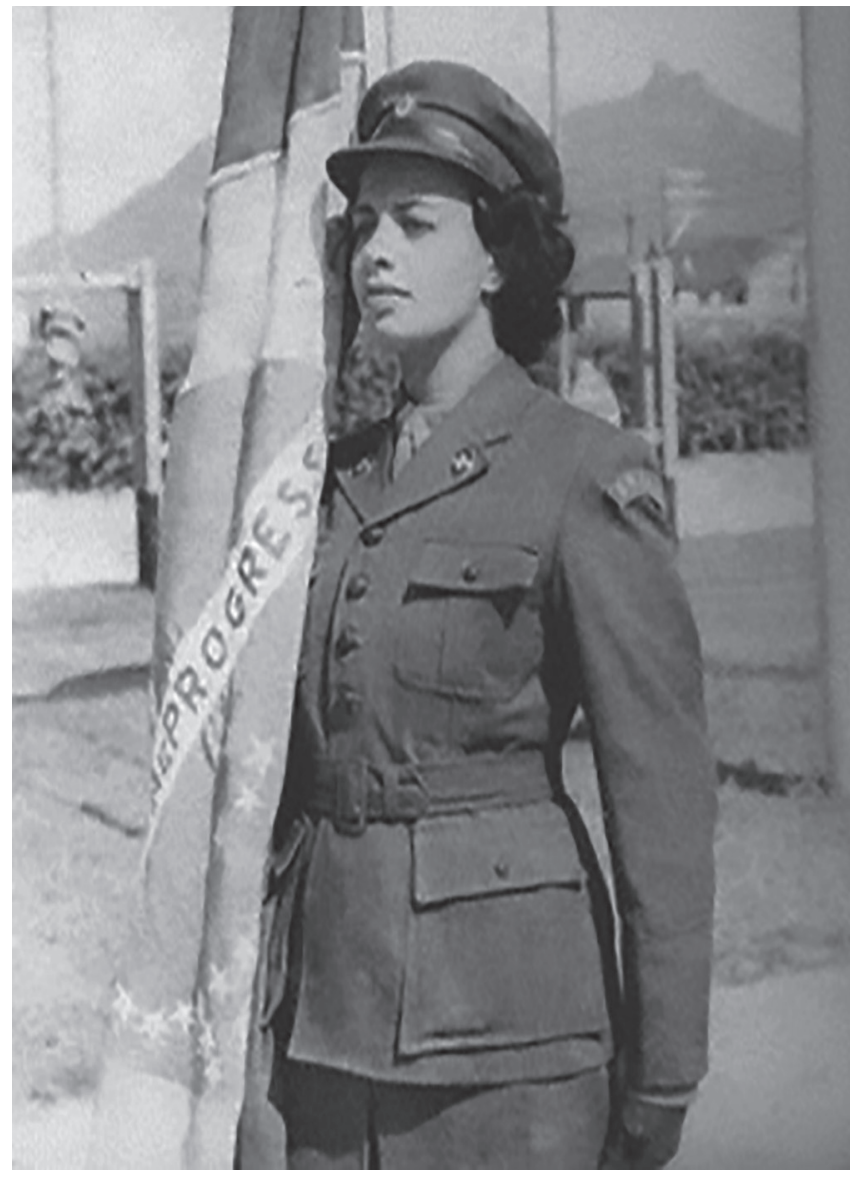

Source: Collection of Oswaldo Cruz Foundation

Figure 2 - Olive green military uniform with the jacket of the nurses from Brazilian Expeditionary Force, 1943

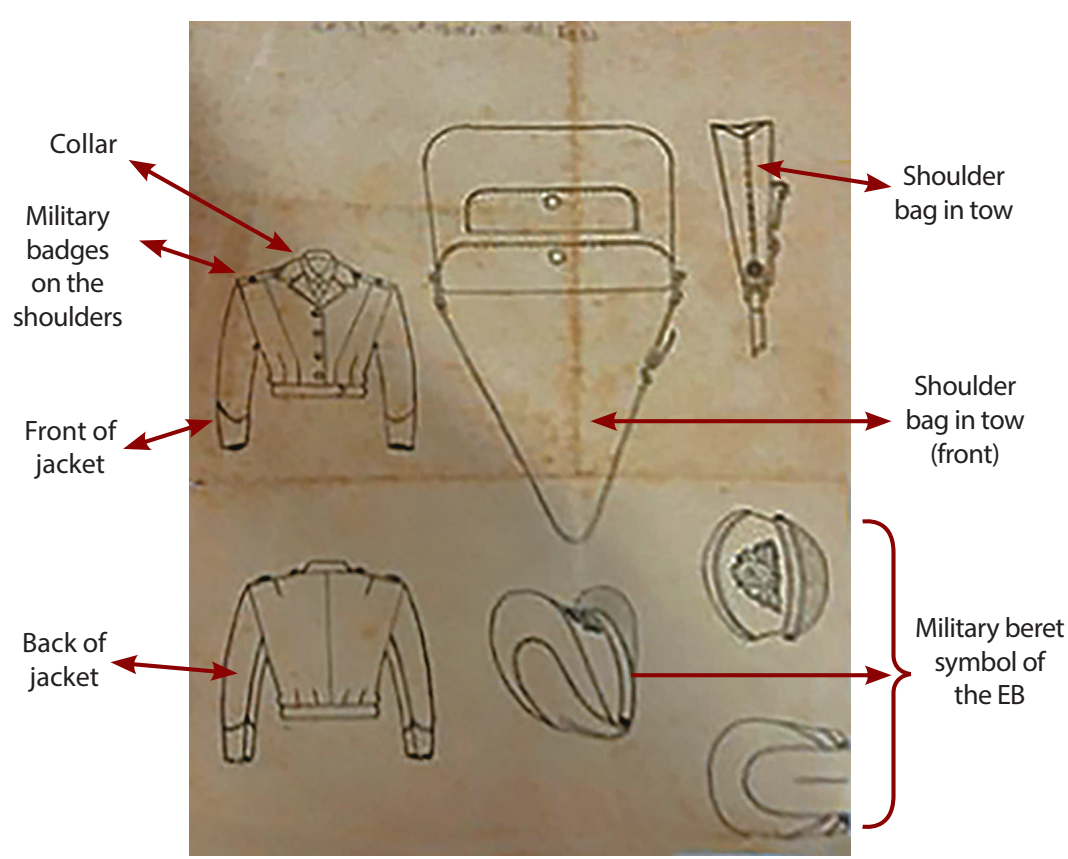

Source: Collection of Oswaldo Cruz Foundation

Figure 1 - Nankin sketch of the uniform drawn by the nurse Virginia Maria de Niemeyer Portocarrero, 1943
The photograph shows attributes worn by the agent, who wears gabardine uniform made exclusively for the members of the female nursing corps. The nurse's head is covered with a beret, which has a badge of the coat of arms of EB in its central part. His clothing consists of belted jacket, shirt with tie and skirt.

The long-sleeved coat, buttoned with four big dark buttons, has four pockets with external singlewelt and black small buttons closing them, being the two of the top smaller than those below. The left collar has an oval badge. The uniform is longsleeved and has an armband with the country of origin in uppercase on the top of the sleeve, on the left shoulder. The jacket has a belt of about five centimeters, with covered buckle. Underneath the jacket, she wears a shirt with a tie. Her hands are covered with gloves apparently made of leather. The Brazilian flag is on her right shoulder. The collar of the coat has an emblem on both sides, as well as a star on the top and in the central part of the single-welt pocket of each shoulder.

She is outdoors, in a landscape whose environment has a big dimension. These attributes are 


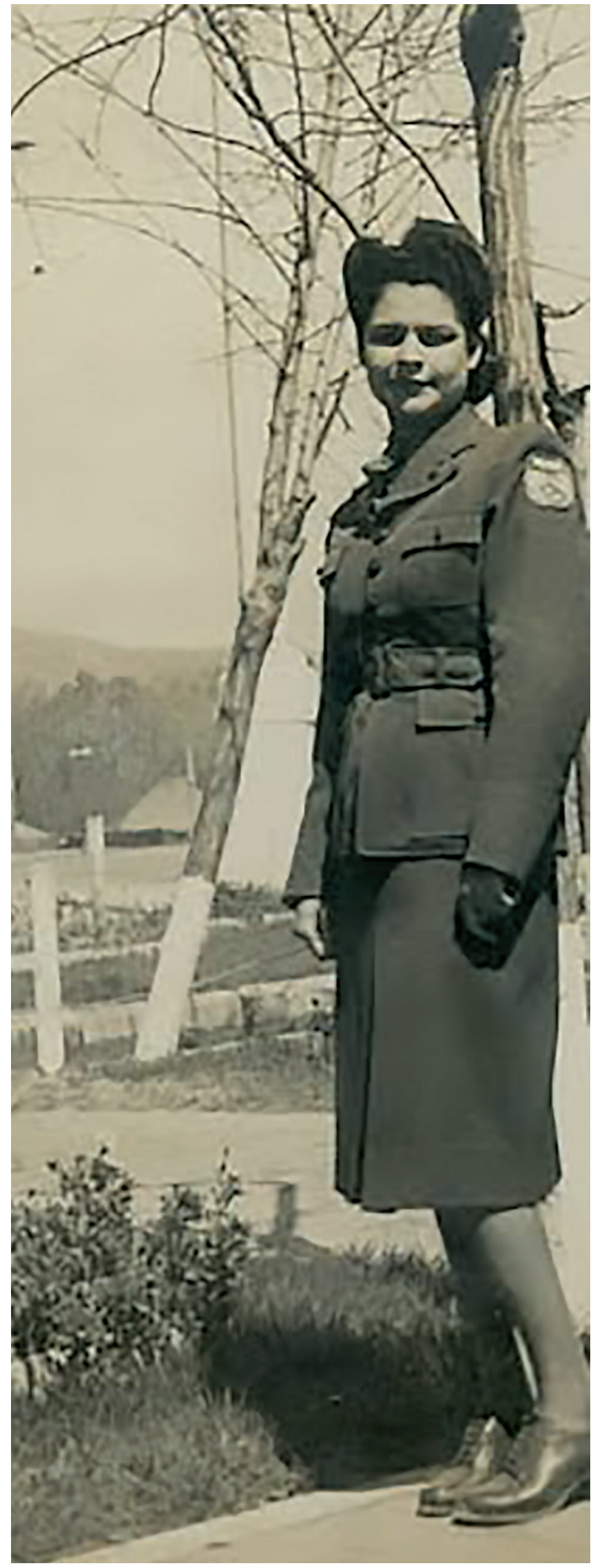

Source: Collection of Oswaldo Cruz Foundation

Figura 3 - Nurse Jandyra Faria de Almeida in the Italian front, 1943 beams, ropes, a low wall, grass floor, and a mountain drawing the geographic contour of Rio de Janeiro, in the space for physical training of EB military personnel.

Figure 3 shows the nurse Jandyra Faria de Almeida, born in Itaparica, Bahia. She wears the same uniform displayed in Figure 2. In this image, more details of the lower part of the uniform can be seen, namely: a divided skirt and a pair of dark shoes.

The picture, also individual, was taken on the Italian front. The scene is outdoors, with a mountain landscape in the background. The floor is flat, with a garden on the side. A low fence and more vegetation can be seen. By observing the shadow, one can infer that it was a sunny day.

It must be emphasized that the uniforms in the images have their own meaning, explaining the function and position of those who wear it. In a military camp, it use is mandatory and non-transferable.

\section{DISCUSSION}

In this study, the officer walking uniform worn by two FEB nurses in the pictures are on focus, communicating the meanings and values instilled in their garments, which, ultimately, aimed at characterizing them as military nurses from the $E B$, in the context of the World War II. Indeed, the military uniform tends to legitimize the authority and the hierarchy of those who wear it and the model created should be used as formal and social clothing. At the same time, the idea that the nurse's uniform can be an artifact capable of promoting confidence in the relationship with patients is evidenced.

The image of the selected sketch shows the drawing is a document from a archive, has characteristics pointing that it is intact and authentic, qualities that suggest it has not been modified. Therefore, its original condition of reliability was maintained, which justifies, essentially, the interest of the researchers. It is evidenced in this sketch, as a document from an archive, a secondary value present in the creation of memory expressed in the nurses' clothing in that context.

Other authors ${ }^{(11-12)}$ identified the power and influence that the uniform, particularly, may have for the nurse's general image. The uniform would be the tangible aspect, or mark, opposing to the intangible aspect, realized through the Bourdieu's sociology, for example, on how the nurse behaves.

Figure 2 refers to the old photographic records, with lowsensitivity plates, which obliged the pictured person to be exposed for a long time, forcing him/her to remain motionless and posing.

In the collar of the coat a badge can be seen. The nurse Virginia Portocarrero affirmed that: "the badge consisted of a gold cross under the onyx. We all had it. This cross was only ours, of the nurses"(13).

This image demarcates the final moments of the nurses in Brazil before leaving for Italy. It shows the use of the uniform includes the formal posture assumed by the group wearing the uniform, in which the latter is a powerful ally in the shaping of behavior. To wear it, the professionals incorporate a role that make them act according to social expectations and focused on the corporate commitment, which is an ideological apparatus that controls their actions, habits and posture ${ }^{(14)}$. 
In addition to adorn, the clothing protect, warms and embraces their bodies, also involving their self-image, wishes and their intended professional image. Society has its dress standards, and they can clarify the way certain relationships of power and identity constructions works.

Some records from the military nurses' scrapbooks point out that Darcy Vargas, wife of the then President of the Republic, Getúlio Dornelles Vargas, and Santinha Dutra, wife of the minister of war during the conflict, Eurico Gaspar Dutra, defined the model of the uniforms of Women's Army Corps ${ }^{(13)}$.

Faced with the alleged difficulty in defining female uniforms of the first women officially incorporated into the ranks of the EB, these authorities manipulated their wives to do so. In turn, these ladies manipulated the decisions made, because, even not being nurses or not participating in the conflict, they took the responsibility for creating the volunteers' uniforms, deciding without consulting who would in fact wear them in the everyday life of war work.

The first five nurses who left Brazil not even received their army service uniforms, given the urgency of the travel. Thus, they worked for 20 days wearing their olive green gabardine officer walking uniform, which was neither functional nor suitable for working in field hospitals. After conciliation between the Brazilian and American delegations, the decision was that the FEB nurses would start using the American summer military uniform for service activities, and the Brazilian olive green gabardine uniform would be worn only in their free times ${ }^{(2)}$.

In Figure 3, the body hexis reveals head to the left side and eyes towards the photographic plate. A helpful and complacent smile, which is expected from a military nurse. Showing positivity was part of the body hexis in their work as professionals caring for those with war wounds. On the left arm of her jacket there is a logo, not found in Figure 2. It is the symbol of the Brazilian Expeditionary Force, which shows a snake smoking.

Interestingly, in the military uniform she worn, her military outpost could not be identified. This is one of the aspects that refers to the nurse's symbolic fight in the process of inclusion in the military field, because, even before departure to the Italian theater of operations, they had not defined their outpost in the army chain of command. Such a problem was partially solved by the Colonel's doctor Emmanuel Marques Porto, head of the FEB health service, who guided the nurses to put the stars in the rank of second lieutenant on the shoulders of their olive green uniform, when they were already in Italy. However, their salary was not compatible with the rank of second lieutenant ${ }^{(2)}$.

Fashion studies explain that, in the 1940s, trousers were not appropriate for women. However, the insertion of women in that mannish universe, working in war zone, brought the need for adaptation to more operational formats of clothes.

In fact, the adaptation of the skirt to the pants transvested the female to male clothing. Thus, the use of trousers, which was particularly controversial among women, started being required as a sign of modernity in a context in which the identities of women and men were defined and fixed by physical, cultural, psychological and intellectual parameters ${ }^{(15)}$.

Nevertheless, the use of divided skirts by nurses was a practical solution to the female body movements in the health care in war context. In both images, the nurses were photographed wearing this type of skirt. Therefore, the divided skirts in the uniforms did not disrupt gender identity, but were in the field of representations of nurses as agents who worn clothes to work on behalf of men, reaffirming the role of each one in the front: men wearing trousers to fight and women wearing pants to care for. Thus, the opposite principles of male and female identities appears in the permanent form of using the body or maintaining the posture, becoming a particular ethics natural ${ }^{(16)}$.

The difference between the uniform registered in the two photographs is the symbol of the snake smoking on the left arm of the nurse Jandyra, whose photography was taken in Italy, after receiving the symbol.

The other items (beret, tie and belt), composing the clothing, represent mannish objects present in the composition of the soldiers' uniform. The nurse is upright, a posture related, among other things, to the need for maintaining the beret on her head. Using a tie in the collar is a male habit and, regardless of the way one tie it, irritates the neck and causes discomfort ${ }^{(17)}$.

The signs with specific characteristics of the institution in the uniform, both of soldiers and nurses, are considered indicators of tradition, hierarchy and discipline, which guided the formation of the habitus of the volunteer citizens, men or women, in reference to the incorporation of authority and trust, which are virtues necessary to the promotion of a speech to protect the country's sovereignty ${ }^{(15)}$.

In addition, both pictures are different regarding a certain tension in the first image, of the nurse Lúcia Osório, and a reserved relaxation, of the nurse Jandyra Almeida, in the second. The latter, by allowing someone photographing her with the symbol visible on his left arm, showed the speech behind the symbol. The symbol of the snake smoking was used in Brazilian military uniforms during the campaign in Italy. It was created after suggestion of the North American allies, who traditionally used badges that identified the origin of their military groups immediately.

The meaning of this symbol is rather controversial up to date. "The Snake is smoking" was an expression of consensus of the Brazilian soldiers, being officialized as an emblem of FEB in the World War II. The veterans claim that this symbol arose because of the negative impression about the FEB before its departure to war, which claimed to be easier to a snake smoking than FEB go to Europe to combat the nazi-fascist troops. This disrepute was encouraged in Brazil by politicians in opposition to the federal government and by civil society itself, due to the precarious conditions of recruitment of soldiers. However, after declaring war on the axis countries, FEB soldiers "made the snake smoke"(18).

In the military field, the uniform identifies who dresses him, placing the person in a hierarchy, as well as providing information about their accomplishments and merits by exhibiting medals. Therefore, it symbolizes a different form of consecrated clothing, being determined by others' decision, with schemes of belonging to the institution and groups, which in terms of spoken discourse represents to be associated with control and censorship ${ }^{(15)}$.

The uniform, in the Armed Forces, has the explicit function of allowing immediate identification of the hierarchical position to which the person belongs. Thus, the social body of the troops agrees with the domain of the State through the use of uniforms. The headquarters subjects the soldiers to daily administrative detailing, 
ordering their actions, determining the conduct and habits due to the representation of the power of these men in their uniforms ${ }^{(19)}$.

Therefore, the uniform visually fits the members into a social context, as well as allows them to identify with the immediate meaning of the power they have, through the garments and adornments belonging to their outposts and ranks, regardless of what they are as people or what they have as cultural capital, the social positions they occupy, and their family and socioeconomic origin. Soon, the uniforms equate and even, respectively, their powers, according to their outposts. In general, the uniforms have a common trait: "create or recreate original action forms of strong symbolic content in their purposes and their means"(5). Besides the nursing professionals have the responsibility to maintain and promote a proper image, because this must be the appearance of a person or profession that is designed for society, which, in turn, understands, recognizes and inserts it ${ }^{(20)}$.

For the World War II, the uniforms of the entire Brazilian troop was made with low-quality and low-cost fabric, which caused embarrassment and discomfort to the army commander of the FEB, marshal Mascarenhas de Moraes. He was not responsible for choosing the material used, but he should, as the head of the Brazilian troops, acknowledge the mistakes. The discomfort and apprehension of the American, British, French, and Russian ally soldiers when they saw the olive green uniforms, very similar to those of the German enemies, was clear, which caused confusion, especially in the advanced outposts and in the patrol of sectors parallel to or surrounding those of the American troop ${ }^{(21)}$.

Despite the challenges, successes and mistakes, the fact that the nurses worn the uniform regularly worked as a symbolic gain, once the uniform of a nurse can constitute a powerful strategy to make them identify with their profession ${ }^{(12)}$.

When the nurses joined the FEB and worn their uniforms, they inaugurated a type of nursing in Brazil, the military Nursing. Their specific garments were designed to act in an atypical war condition, but also represented visually a social norm of belonging to that group. This is so true that the assimilation of military habitus would be favored by the systematic use of uniforms. This represents a strategy to assure the inclusion of these nurses in the military field, which also served to strengthen the sense of belonging and unity of the corps through the homogenization of attitudes, gestures and practices.

\section{Study limitations}

Although this study has been carried out with a reduced number of images, which can be considered a limitation in a broader analysis, the results demarcate, through the visual communication, the integration of nurses in institutions culturally masculinized, as the Armed Forces.

\section{Contributions to the field of Nursing}

This search of pictures of the Brazilian nurses' military uniforms and its meaning, as part of the strengthening of the military nurse professional identity, sought to contribute to the construction of the history of nursing through visual communication in the context of World War II.

When certain group starts to work, its physical appearance and the garments used are consecrated. The habits seem to emerge naturally in its environment, being recognized for being understood as the way to act in a given situation. This occurs until new changes are valued. Thus, visual culture contributes to the identification of the professional nurse and is continually formed and transformed by individuals in organizational spaces so that they are recognized by their clothing and its characteristics, such as adornments, badges, color, type of fabric and shaping.

\section{FINAL CONSIDERATIONS}

This study focused on the uniform as a clothing that has signs of the identity of the Brazilian Armed Forces in the World War II, used to reinforce and convey institutional values through nonverbal visual communication. Therefore, the FEB nurses, by wearing and shaping their bodies with uniforms with emblems, symbols of professional identity, also gave visibility to their inclusion, proclaiming the symbolic fight for including signs and female practices in a field culturally considered for men, during the world conflict. The effects of the submission to schemes, rules and rituals of the military field resulted in the inclusion of the nurses systematically marked by the gender issues, in that context.

The uniforms are present throughout the military life, from recruitment to discharge, and support the promotion of the self-esteem of those who wear it. In the case of nurses from the $\mathrm{FEB}$, it conferred distinction in the EB, but not necessarily in the field of nursing. They remained between the walls of the barracks after the war ended and, thus, unknown.

About these signs of forgetfulness, the Canção do expedicionário (Song of the Expeditionary), an emblematic song of the soldiers who were incorporated into FEB during the World War II, questions in its lyrics: "Do you know where I come from?". This includes the nurses, and is still waiting for an answer.

\section{REFERENCES}

1. Presidência da República (BR), Casa Civil, Subchefia para Assuntos Jurídicos. Decreto no 10.358, de 31 de agosto de 1942. Declara o estado de guerra em todo o território nacional [Internet]. Diário Oficial da União: República Federativa do Brasil; 1942 [cited 2017 Dec 23]. Aug 31, Seção 1: [about 1 screen]. Available from: http://www.planalto.gov.br/ccivil_03/decreto/1930-1949/d10358.htm

2. Portocarrero VMN. A mulher brasileira apresentou-se voluntariamente. Rev Exerc Bras. 1994;131(3):59-63.

3. Ribeiro JS, Santos FV. Do quimono à casaca: transformações e marcas identitárias no indumentário japonês. Rev Transversos [Internet]. 2017 [cited 2018 Jan 10];9:265-279. Available from: doi: 10.12957/transversos.2017.28398

4. Nacif MCV. As roupas pelo avesso: cultura material e história social do vestuário [Internet]. In: Anais do 9 Colóquio de Moda. Fortaleza (CE): 
The Brazilian Army nurses' uniforms: visual identity in World War II Bernardes MMR, Oliveira AB, Kaminitz S, Gomes AMT, Marques SC, Porto FR.

Universidade Federal do Ceára; 2013 [cited 2017 Dec 28]. Sep 9-11; 2013. Available from: https://bit.ly/2xLQ1oX

5. Bourdieu P. O poder simbólico. 16th ed. Rio de Janeiro: Bertrand Brasil; 2012. 176 p.

6. Presidência da República (BR), Casa Civil, Subchefia para Assuntos Jurídicos. Lei no 9.610, de 19 de fevereiro de 1988. Altera, atualiza e consolida a legislação sobre direitos autorais e dá outras providências [Internet]. Diário Oficial da União: República Federativa do Brasil; 1998 [cited 2018 Nov 3]. Feb 20, seção 1: [about 4 screens]. Available from: http://www.planalto.gov.br/ccivil_03/leis/L9610.htm

7. Ministério da Saúde (BR), Conselho Nacional de Saúde. Resolução n 510, de 7 de abril de 2016. Dispõe sobre as normas aplicáveis a pesquisas em Ciências Humanas e Sociais cujos procedimentos metodológicos envolvam a utilização de dados diretamente obtidos com os participantes ou de informações identificáveis ou que possam acarretar riscos maiores do que os existentes na vida cotidiana, na forma definida nesta Resolução [Internet]. Diário Oficial da União: República Federativa do Brasil; 2016[cited 2018 Nov 3] May 24. Seção 1: [about 5 screens]. Available from: http://bvsms.saude.gov.br/bvs/saudelegis/cns/2016/res0510_07_04_2016.html

8. Neto MO, Porto FR, Nascimento SA. Application of semiotics in the analysis of facsimiles: a documentary research. Online Braz J Nurs [Internet]. 2012 [cited 2017 Nov 25];11(3):848-64. Available from: http://www.objnursing.uff.br/index.php/nursing/ article/view/3705/html

9. Oliveira AB, Bernardes MMR, Kneodler TS, Lourenço MBC. Memories revealed: veteran nurses discourses on their fight for reinstatement in the military field. Rev Texto Contexto Enferm [Internet]. 2017 [cited 2018 Jan 16];26(3):e2720016. Available from: http://dx.doi. org/10.1590/0104-07072017002720016

10. Oliveira AB, Santos TCF, Padilha MICS, Oliveira ARP, Peres MAA, Cesário MB. "At the front of the sexes": the march of Brazilian nurses to gain military service. Rev Eletr Enf [Internet]. 2013 [cited 2017 Nov 28];15(3):638-47. Available from: http://dx.doi.org/10.5216/ree.v15i3.17446 Portuguese.

11. Fogle C, Reams P. Taking a uniform approach to nursing attire. Nursing [Internet]. 2014 [cited 2018 Jan 15];44(6):50-4. Available from: doi: 10.1097/01.NURSE.0000444535.96822.3b

12. Wocial LD, Sego K, Rager C, Laubersheimer S, Everett LQ. Image is more than a uniform: the promise of assurance. J Nurs Adm [Internet]. 2014 [cited 2018 Jan 18];44(5):298-302. Available from: doi: 10.1097/NNA.0000000000000070

13. Bernardes MMR. Enfermeiras brasileiras na 2a Guerra Mundial: uma abordagem sob olhar fotográfico 1942-1945 [Internet]. Rio de Janeiro: Exército Brasileiro e Universidade do Estado do Rio de Janeiro; 2003 [cited 2018 Nov 3]. Video: 20:18 min. Available from: https://www. youtube.com/watch?v=Dv4-ZAkj07Y\&t=31s

14. Martins EF, Martins CJ. [The uniform as a representative object in health care area]. Verso e Reverso [Internet]. 2011 [cited 2018 Jan 18];25(59):100-8. Available from: doi: 10.4013/ver.2011.25.59.03 Portuguese.

15. Simili IG. Education and fashion production during the second world war: the volunteers of brazilian legion of assistance. Cad Pagu [Internet]. 2008 [cited 2018 Jan 10];31:439-69. Available from: http://dx.doi.org/10.1590/S0104-83332008000200019 Portuguese

16. Bourdieu P. A economia das trocas linguísticas: o que falar quer dizer. 2nd ed. São Paulo: Edusp; 1998. 222 p.

17. Bates C. Looking closely: material and visual approaches to the nurse's uniform. Nurs Hist Rev [Internet]. 2010 [cited 2018 Jan 6];18:167-88. Available from: doi: 10.1891/1062-8061.18.167

18. Haag C. Por quem a cobra fumou. Rev Pesq Fapesp [Internet]. 2010 [cited 2017 Dec 11];177:84-7. Available from: http://revistapesquisa. fapesp.br/2010/11/25/por-quem-a-cobra-fumou/

19. Souza AB. O exército na consolidação do Império. Rio de Janeiro: Ministério da Jústica, Arquivo Nacional; 1999.

20. Román CAL. El uniforme y su influencia en la imagem social. Rev Cubana Enfermer [Internet]. 2006 [cited 19 Jan 2018];22(1):1-15. Available from: http://www.bvs.sld.cu/revistas/enf/vol22_1_06/enf06106.htm

21. Silveira JX. A FEB por um soldado. Rio de Janeiro: Expressão e Cultura; 2000. 